\title{
Protective effect of bixin on carbon tetrachloride-induced hepatotoxicity in rats
}

\author{
Priscila R Moreira ${ }^{1}$, Marcos A Maioli', Hyllana CD Medeiros ${ }^{1}$, Marieli Guelfi ${ }^{1}$, Flávia TV Pereira ${ }^{2}$ \\ and Fábio E Mingatto ${ }^{1 *}$
}

\begin{abstract}
Background: The liver is an important organ for its ability to transform xenobiotics, making the liver tissue a prime target for toxic substances. The carotenoid bixin present in annatto is an antioxidant that can protect cells and tissues against the deleterious effects of free radicals. In this study, we evaluated the protective effect of bixin on liver damage induced by carbon tetrachloride $\left(\mathrm{CCl}_{4}\right)$ in rats.

Results: The animals were divided into four groups with six rats in each group. $\mathrm{CCl}_{4}\left(0.125 \mathrm{~mL} \mathrm{~kg}^{-1}\right.$ body wt.) was injected intraperitoneally, and bixin $\left(5.0 \mathrm{mg} \mathrm{kg}^{-1}\right.$ body wt.) was given by gavage 7 days before the $\mathrm{CCl}_{4}$ injection. Bixin prevented the liver damage caused by $\mathrm{CCl}_{4}$, as noted by the significant decrease in serum aminotransferases release. Bixin protected the liver against the oxidizing effects of $\mathrm{CCl}_{4}$ by preventing a decrease in glutathione reductase activity and the levels of reduced glutathione and NADPH. The peroxidation of membrane lipids and histopathological damage of the liver was significantly prevented by bixin treatment.

Conclusion: Therefore, we can conclude that the protective effect of bixin against hepatotoxicity induced by $\mathrm{CCl}_{4}$ is related to the antioxidant activity of the compound.
\end{abstract}

Keywords: Bixin, Carbon tetrachloride, Hepatotoxicity, Oxidative stress, Protective activity

\section{Background}

The liver is the main organ involved in the biotransformation of exogenous substances (xenobiotics) and has the ability to convert hydrophobic compounds into water-soluble ones that are more easily eliminated by the body [1]. The activity of the liver in the metabolism of xenobiotics is mediated primarily by cytochrome P450 (CYP 450). Although biotransformation reactions are associated with the detoxification process, in some cases, the metabolism of xenobiotics is detrimental to cells due to the production of highly reactive metabolites that are more toxic than the parent compound, such as electrophiles, radicals and reactive oxygen species (ROS), that can react directly with cellular macromolecules or initiate chain reactions [2].

Carbon tetrachloride $\left(\mathrm{CCl}_{4}\right)$ is a small, lipophilic molecule that spreads easily in the lipid compartments of the body and is metabolized in the liver. Its mechanism

\footnotetext{
* Correspondence: fmingatto@dracena.unesp.br

'Laboratório de Bioquímica Metabólica e Toxicológica (LaBMeT), UNESP Univ Estadual Paulista, Campus de Dracena, Dracena, SP 17900-000, Brazil Full list of author information is available at the end of the article
}

of toxicity requires a CYP 450-mediated bioactivation step that produces free radicals, such as trichloromethyl $\left(\mathrm{CCl}_{3}\right)$ [3], and induces the peroxidation of lipids. These lipids then damage the membranes of organelles and liver cells, causing the swelling and necrosis of hepatocytes and resulting in the release of cytosolic enzymes such as alanine aminotransferase (ALT) and aspartate aminotransferase (AST) into the circulating blood (Singh et al., 1998; [4,5]). Due to these properties, $\mathrm{CCl}_{4}$ is a chemical that is widely used to induce liver damage in experimental studies [6-10].

The species Bixa orellana L. belongs to the family Bixaceae and is popularly known as annatto. The main use of annatto is as a dye. Among the natural colors, annatto is most used by the food industry, especially in the preparation of butter, cheeses, bakery products, oils, ice cream, cereals and meats [11,12]. In addition to its use in coloring, annatto is also used in folk medicine for the treatment of coronary diseases, disorders of the stomach and intestine, respiratory disorders, burns, and as an aphrodisiac. Annatto leaves are used to fight kidney disease and fever [13,14], and the tincture prepared from 
the leaves, immature fruit and flower organs have been shown to present antimicrobial activity [15]. Recently, [16] demonstrated that the aqueous extract of the seeds of Bixa orellana was capable of reversing the hypertriglyceridemia induced by Triton, fructose and ethanol, demonstrating a hypolipidemic effect.

The main product of annatto is the seed, from which bixin, a dye of group of carotenoids of great interest in national and international markets, is extracted. Bixin is one of the most effective suppressors of biological molecular oxygen and can protect cells and tissues against the harmful effects of free radicals; additionally, bixin is also an effective inhibitor of lipid peroxidation [17-19]. In the present study, we aimed to investigate the potential effects of bixin in reducing damage and oxidative stress and in improving histopathological abnormalities in the liver of rats treated with $\mathrm{CCl}_{4}$ in order to determine the potential of this compound for the treatment or prevention of liver disease.

\section{Results}

Analysis of alanine aminotransferase (ALT) and aspartate aminotransferase (AST) enzyme activities

Figure 1 shows the effect of bixin on ALT (A) and AST (B) activities in serum. Hepatotoxicity was verified by a significant increase in ALT and AST activities in the $\mathrm{CCl}_{4}$-treated group compared with the control group. Pretreatment with bixin significantly prevented the release of these enzymes compared with the $\mathrm{CCl}_{4}$-only treated group in serum. The prevention was only partial since the activities of the enzymes from rats treated with $\mathrm{CCl}_{4}$ and bixin are significantly different from control. Bixin alone did not have any effect on enzyme activity.

\section{Lipid peroxidation}

A significant increase in the level of MDA, an end product of lipid peroxidation, was observed in the liver of $\mathrm{CCl}_{4}$-treated rats when compared with the control group (Figure 2). Pretreatment with bixin significantly prevented the MDA production in the liver when compared with that of rats administered $\mathrm{CCl}_{4}$. Bixin alone did not have any effect on this parameter.

\section{Determination of GSH and NADPH levels on liver homogenate}

Treatment of rats with $\mathrm{CCl}_{4}$ significantly reduced the levels of GSH and NADPH in the liver when compared with the control group (Figures $3 \mathrm{~A}$ and $\mathrm{B}$, respectively). The pretreatment of animals with bixin significantly prevented these changes, maintaining levels of the compounds to the normal range. Bixin alone did not have any effect on these parameters.

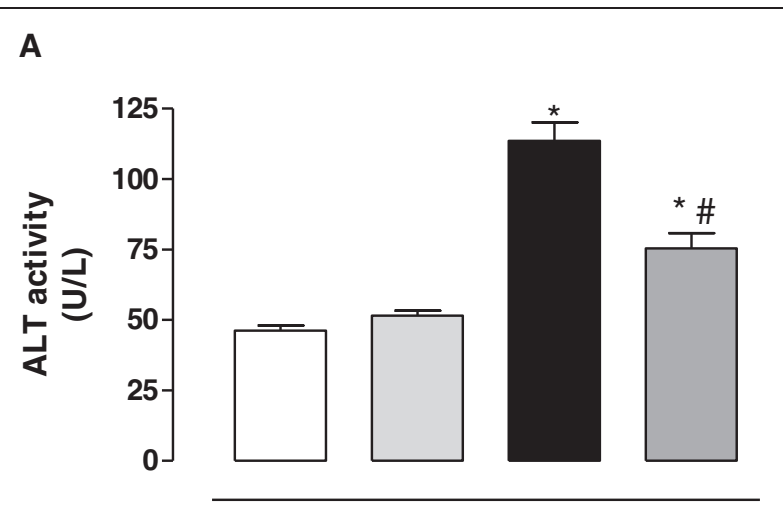

B

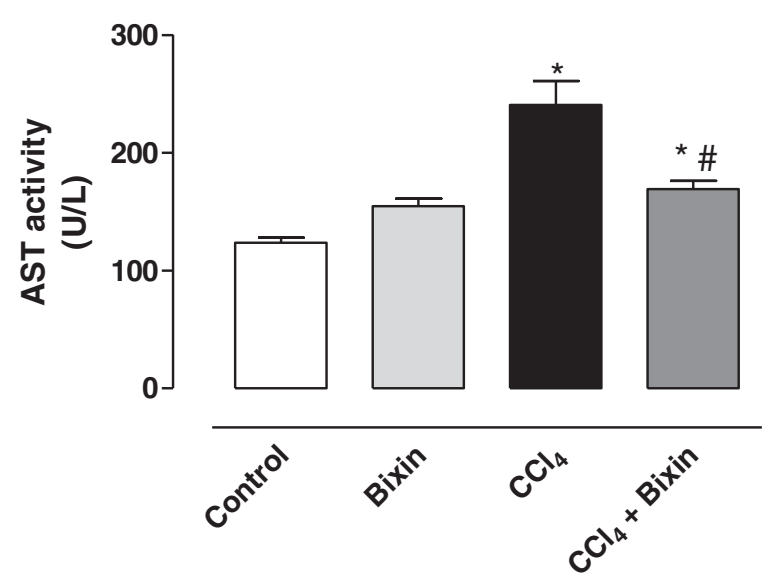

Figure 1 The effects of bixin on $\mathrm{CCl}_{4}$-induced hepatotoxicity evaluated by ALT (A) and AST (B) activities in the serum. The results represent the mean \pm SEM of six animals per group. * Significantly different from the control group $(P<0.05)$. "Significantly different from the $\mathrm{CCl}_{4}$-only group $(\mathrm{P}<0.05)$.

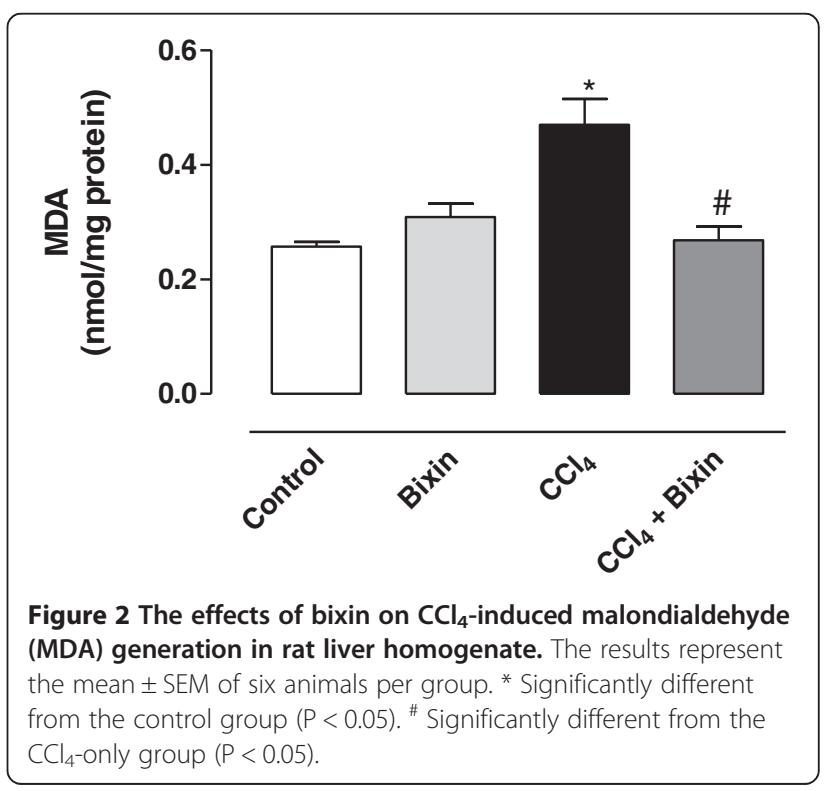




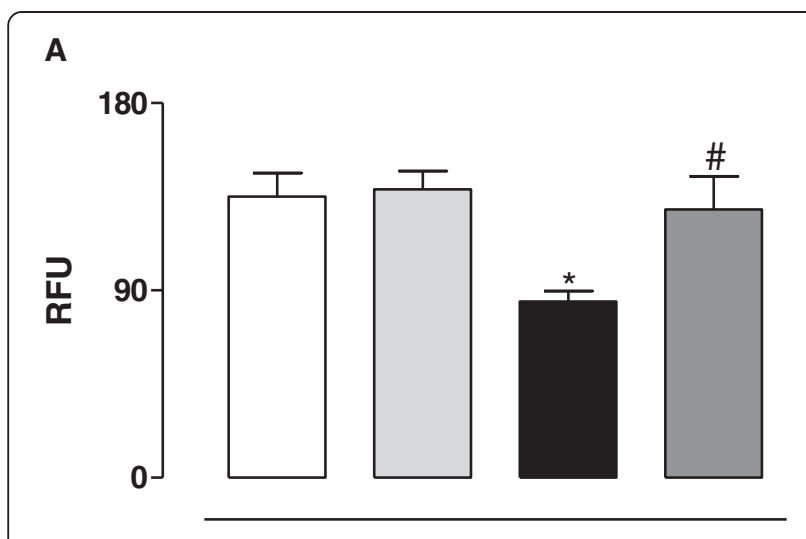

B

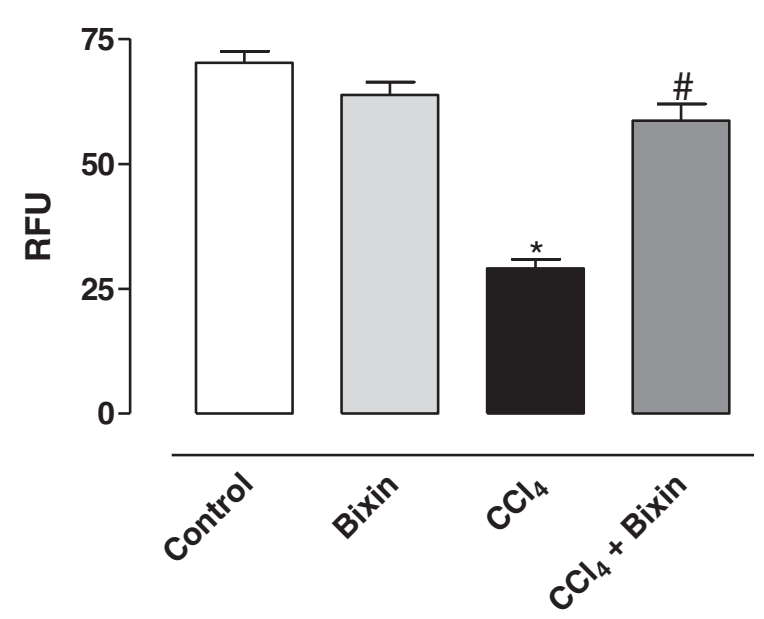

Figure 3 The effects of bixin on $\mathrm{CCl}_{4}$-induced GSH (A) and NADPH (B) oxidation in rat liver homogenate. The results represent the mean \pm SEM of six animals per group. * Significantly different from the control group $(P<0.05)$. " Significantly different from the $\mathrm{CCl}_{4}$-only group $(\mathrm{P}<0.05)$. RFU: Relative Fluorescence Unit.

\section{Analysis of glutathione reductase activity}

Analysis of glutathione reductase (GR) activity showed a significant reduction in activity in the $\mathrm{CCl}_{4}$-treated group when compared to the control group (Figure 4). Pretreatment of animals with bixin prevented the change in GR activity, showing a protection against the effects of $\mathrm{CCl}_{4}$. Bixin alone did not have any effect on enzyme activity.

\section{Histopathological analysis}

Histopathological studies of the liver of control and bixinonly treated animals showed normal histology (Figures 5A and $\mathrm{B}$, respectively). In animals treated with $\mathrm{CCl}_{4}$, inflammation, necrosis and hydropic degeneration of hepatic cells was observed (Figure 5C). The group that was pretreated with bixin showed that severe hepatic lesions induced by $\mathrm{CCl}_{4}$ were partially prevented (Figure $5 \mathrm{D}$ ), which were in agreement with the results of the serum aminotransferases activities and lipid peroxidation.

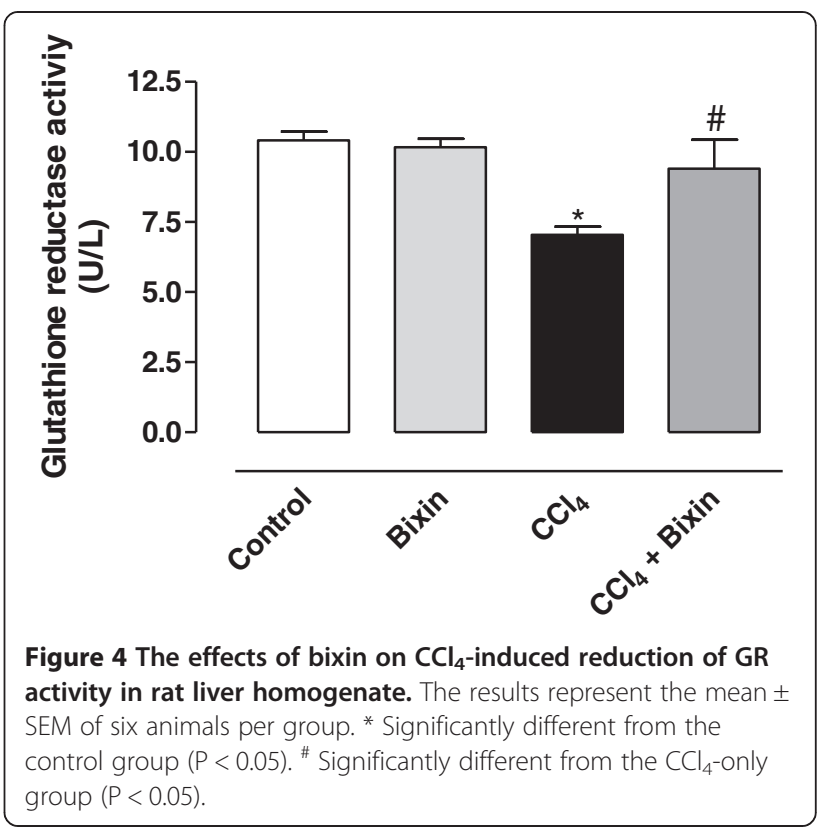

\section{Discussion and conclusion}

The liver plays an important role in metabolism and biotransformation of xenobiotics. Due to its position between the digestive tract and circulatory system, it receives large amounts of nutrients and xenobiotics absorbed through the digestive tract and the portal vein becoming the target organ of several classes of toxins and toxicants, natural or synthetic [1].

Bixin, a carotenoid with one carboxylic acid and one methyl ester group, is the major pigment found in annatto and corresponds to approximately $80 \%$ of the carotenoids present in the plant seed $[20,21]$. This compound has been demonstrated to protect cells and tissues against the deleterious effects of ROS and free radicals and also exhibits a cholesterol lowering effect $[17,18,22-24]$. In a previous study, [2] evaluated the role of bixin on cisplatin-induced oxidative stress in the kidneys of Wistar rats at doses of 2.5 or $5.0 \mathrm{mg} \mathrm{kg}^{-1}$ body wt. by gavage. Pretreatment with the highest dose of bixin resulted in a reduction in the total number of chromosome aberrations, inhibited increases in lipid peroxidation, and inhibited renal glutathione depletion induced by cisplatin. Therefore, in our study we decide to evaluate the potential hepatoprotective effects of bixin using this same dose.

$\mathrm{CCl}_{4}$ is a hepatotoxin that causes liver damage and has been used in several studies as a hepatotoxic agent [5,8,25-28]. The most striking pathological features of $\mathrm{CCl}_{4}$-induced hepatotoxicity are hepatic steatosis, cirrhosis and necrosis, which results from the formation of reactive radical intermediates such as trichloromethyl $\left(\mathrm{CCl}_{3}{ }^{\circ}\right)$ formed by CYP 450-mediated biotransformation that induces membrane lipid peroxidation $[3,29,30]$. 


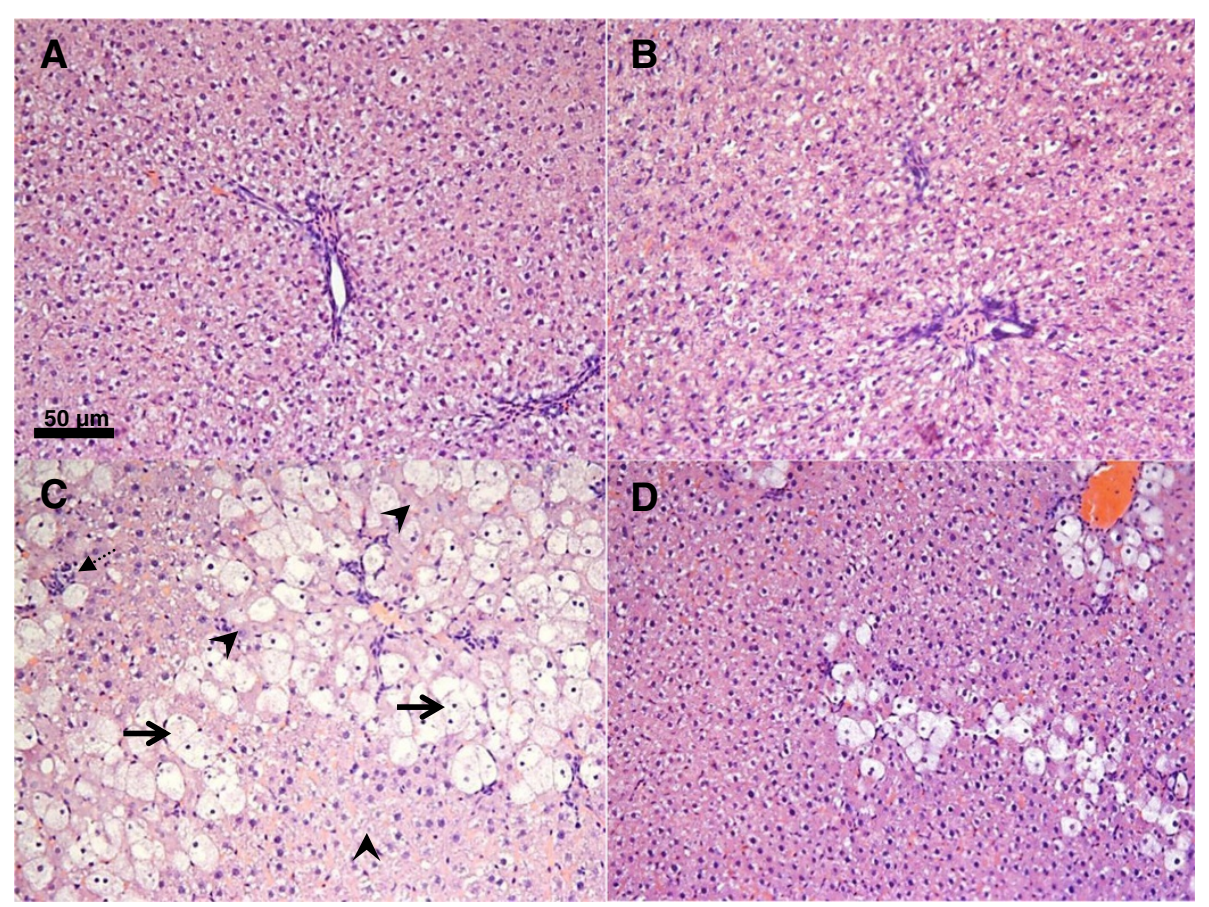

Figure 5 The effects of bixin on $\mathrm{CC}_{4}$-induced liver damage in rat. (A) liver of control group showing intact liver structures; (B) liver of bixin group, showing normal structure; (C) liver of $\mathrm{CCl}_{4}$ group, showing hepatocytes necrosis (arrow head), hydropic degeneration (arrow) and infiltration of inflammatory cells (dashed arrow); and (D) liver of $\mathrm{CCl}_{4}+$ bixin showing prevented damage. H\&E, original magnification $200 \times$.

The serum activities of alanine transaminase (ALT) and aspartate transaminase (AST) are used as an indication of the extent of liver damage due to the release of large quantities of these enzymes into the bloodstream [31]. AST is distributed in body tissues, including muscle and the heart. In the liver, AST is mainly present in the mitochondria of hepatocytes while the ALT is found outside of the mitochondria. $\mathrm{CCl}_{4}$ induces the peroxidation of lipids that damage the membranes of liver cells and organelles and results in the release of ALT and AST into the circulating blood [5]. Accordingly, our results demonstrated that treatment with $\mathrm{CCl}_{4}$ promoted a significant increase in ALT and AST serum activities. Pretreatment with bixin protected the liver from damage by $\mathrm{CCl}_{4}$, as there was a significant decrease in the release of enzymes.

As mentioned above, the hepatotoxic effects of the metabolism of $\mathrm{CCl}_{4}$ are mainly due to its active metabolite, the trichloromethyl radical, which in the presence of oxygen, is transformed into trichloromethyl peroxyl radical $\left(\mathrm{CCl}_{3} \mathrm{OO}\right)$. These free radicals bind covalently to macromolecules and induce peroxidative degradation of membrane lipids that are rich in polyunsaturated fatty acids [23]. This leads to the formation of lipid peroxides that give rise to products such as malondialdehyde (MDA) that cause damage to the membranes [32,33]. The increased $\mathrm{MDA}$ in the liver of $\mathrm{CCl}_{4}$-treated rats suggests that the natural antioxidant defense mechanism to scavenge excessive free radicals has been compromised. However, pretreatment with bixin significantly prevented the formation of MDA, indicating hepatoprotection by impairing initiation and propagation of the peroxidative process.

To protect itself from oxidation damage, the cell has a defense system that includes reduced glutathione (GSH), nicotinamide adenine dinucleotide phosphate in the reduced form (NADPH) and enzymes such as superoxide dismutase (SOD), catalase, glutathione peroxidase (GPx) and glutathione reductase (GR). The imbalance between the formation and removal of free radicals in the body, due to the reduction of endogenous antioxidants or increased generation of oxidizing species, generates a pro-oxidant condition known as oxidative stress, which favors the occurrence of oxidative lesions in macromolecules and cellular structures, and possibly result in cell death [34]. Under conditions of oxidative stress, some of the endogenous protective factors decrease. Accordingly, treatment of animals with $\mathrm{CCl}_{4}$ caused a significant decrease in the levels of GSH and NADPH, and in the activity of the GR. However, we observed a protective effect of bixin on oxidative stress caused by $\mathrm{CCl}_{4}$ because the pretreatment of animals with the compound prevented the oxidation of GSH and NADPH and the reduction of the activity of GR, indicating an indirect antioxidant property of the bixin, probably by reacting with the free radicals arising from $\mathrm{CCl}_{4}$ as demonstrated by [35].

The histological observations in the liver samples strongly support the protective effect of bixin. $\mathrm{CCl}_{4}$ caused various 
histological changes to the liver, including cell necrosis, inflammation, and hydropic degeneration of hepatic cells. These alterations were significantly attenuated by bixin in livers, resulting in only minor hepatocellular necrosis and inflammatory cell infiltration. In conclusion, our results indicate that pretreatment with bixin attenuated liver injury produced by carbon tetrachloride while significantly reducing the alterations caused by ALT and AST activities, lipid peroxidation, and histopathological parameters. Additionally, bixin protected against reduction of GSH and NADPH levels and GR activity. These effects may be related to the antioxidant activity of bixin.

\section{Methods}

\section{Chemicals}

Annatto powder (containing 28\% bixin, determined spectrophotometrically) was kindly supplied by Christian Hansen Indústria e Comércio Ltda (Valinhos, SP, Brazil). The amount of annatto supplied to the animals was adjusted to contain the desired dose of bixin. All other reagents were of the highest commercially available grade.

\section{Animals}

Male Wistar rats weighing approximately $200 \mathrm{~g}$ were used in this study. The animals were obtained from the Central Bioterium of UNESP - Univ Estadual Paulista, Campus de Botucatu, SP, Brazil, and were maintained with a maximum of 4 rats per cage under standard laboratory conditions with water and food provided ad libitum. The experimental protocols were approved by the Ethical Committee for the Use of Laboratory Animals of the UNESP - Univ Estadual Paulista, Campus de Dracena, SP, Brazil.

\section{Treatment}

The animals were divided into four groups, each with 6 animals. Group 1 was the control group, and received canola oil by gavage for 7 days and mineral oil intraperitoneally on the last day. Group 2 was treated with bixin suspended in canola oil ( $5.0 \mathrm{mg} / \mathrm{kg}$ body weight) by gavage for 7 days before mineral oil application. Group 3 received canola oil by gavage for 7 days and $\mathrm{CCl}_{4}$ dissolved in mineral oil ( $0.125 \mathrm{~mL} / \mathrm{kg}$ body weight), administered intraperitoneally, on the last day. Group 4 received bixin suspended in canola oil ( $5.0 \mathrm{mg} / \mathrm{kg}$ body weight) by gavage for 7 days and carbon tetrachloride, administered intraperitoneally, on the last day. Twenty-four hours after the administration of the vehicle or $\mathrm{CCl}_{4}$, animals were euthanized by decapitation and biochemical and histopathological analyses were performed. The dose of bixin ( $5.0 \mathrm{mg} / \mathrm{kg}$ body weight) used in this study as pretreatment, was based on data found in the literature as showing protective effects in the kidney [36].

\section{Analysis of enzymes indicative of hepatic functions}

Blood samples were collected and kept at room tem perature for 15 minutes to allow for coagulation. Serum was separated by low-speed centrifugation (3000 g for $15 \mathrm{~min}$ ), and the activity of the enzymes ALT and AST was measured using commercially available kits (Bioclin, Belo Horizonte, Brazil) according to the manufacturer's protocols.

\section{Preparation of rat liver homogenate}

The liver was removed, sliced into $50 \mathrm{~mL}$ of medium (250 mM sucrose, $1 \mathrm{mM}$ EGTA and $10 \mathrm{mM}$ HEPES$\mathrm{KOH}, \mathrm{pH} 7.2)$ at $4^{\circ} \mathrm{C}$, washed three times with the same medium and homogenized three times for $15 \mathrm{sec}$ at $1 \mathrm{~min}$ intervals with a Potter-Elvehjem homogenizer. The protein concentration of the homogenate was determined by the biuret reaction with BSA as a standard [37].

\section{Membrane lipid peroxidation (LPO) assay}

The level of LPO was estimated by malondialdehyde (MDA) generation [38]. The liver homogenate $(5 \mathrm{mg}$ of protein) was added to a tube. Following the addition of $0.2 \mathrm{~mL}$ of $8.1 \%$ SDS, $1.5 \mathrm{~mL}$ of $20 \%$ acetic acid and $1.5 \mathrm{~mL}$ of $0.67 \%$ thiobarbituric acid (TBA, aqueous solution), glassdistilled deionized water was added to a final volume of $4 \mathrm{~mL}$. The mixture was incubated for $60 \mathrm{~min}$ at $85^{\circ} \mathrm{C}$. The MDA-TBA complex was extracted with $5 \mathrm{~mL}$ of n-butanol and the absorbance was measured at $535 \mathrm{~nm}$. The MDA concentration was calculated with $\varepsilon=1.56 \times 10^{5} \mathrm{M}^{-1} \mathrm{~cm}^{-1}$.

\section{Determination of GSH level}

Liver homogenate ( $1 \mathrm{mg}$ of protein) was added to medium (125 $\mathrm{mM}$ sucrose, $65 \mathrm{mM} \mathrm{KCl}$ and $10 \mathrm{mM}$ HEPES-KOH, $\mathrm{pH} 7.4$ ) to a final volume of $1 \mathrm{~mL}$ and treated with $0.5 \mathrm{~mL}$ of $13 \%$ trichloroacetic acid. The mixture was stirred and then centrifuged at $9000 \mathrm{~g}$ for $3 \mathrm{~min}$. Aliquots $(100 \mu \mathrm{L})$ of the supernatant were mixed with $2 \mathrm{~mL}$ of $100 \mathrm{mM}$ $\mathrm{NaH}_{2} \mathrm{PO}_{4}$ buffer at $\mathrm{pH} 8.0$ containing $5 \mathrm{mM}$ EGTA. One hundred microliters of an o-phthaldialdehyde solution $(1 \mathrm{mg} / \mathrm{mL})$ was added, and the fluorescence was measured 15 min later in a spectrofluorometer (Shimadzu-RFPC 5301, Tokyo, Japan) using 350/420 nm as the excitation/ emission wavelength pair [39]. The data are expressed in relative units of fluorescence.

\section{Determination of NADPH level}

Liver homogenate (1.5 mg protein) was added to medium (125 mM sucrose, $65 \mathrm{mM} \mathrm{KCl}$ and $10 \mathrm{mM}$ HEPES-KOH, $\mathrm{pH} 7.4$ ) to a final volume of $1.5 \mathrm{~mL}$ and centrifuged at $8000 \mathrm{~g}$ for $3 \mathrm{~min}$. The supernatant was collected, and the fluorescence was measured in a spectrofluorometer (Shimadzu-RFPC 5301, Tokyo, Japan) using 366/450 nm as the excitation/emission wavelength pair. The data are expressed in relative units of fluorescence. 


\section{Glutathione reductase activity}

One milliliter of $0.1 \mathrm{mM}$ sodium phosphate buffer, $\mathrm{pH}$ 7.6, with $0.5 \mathrm{mM}$ EDTA, $10 \mu \mathrm{L}$ of $10 \%$ Triton X-100, liver homogenate ( $1 \mathrm{mg}$ of protein) and $10 \mu \mathrm{L}$ of $100 \mathrm{mM}$ GSSG was added to $4 \mathrm{~mL}$ quartz cuvettes. After incubating the samples at $30^{\circ} \mathrm{C}$ for 5 minutes, $10 \mu \mathrm{L}$ of $10 \mathrm{mM} \mathrm{NADPH}$ was added, and the variation in absorbance was determined at a wavelength of $340 \mathrm{~nm}$ in a spectrophotometer (Beckman-Coulter model DU-800, Fullerton, CA, USA).

\section{Histopathological analysis}

Liver fragments were fixed in a $10 \%$ solution of formaldehyde, dehydrated in graduated ethanol (50-100\%), cleared in xylene and embedded in paraffin. The hepatic sections (4-5 $\mu \mathrm{m})$ were analyzed by light microscopy with a magnification of 200x after staining with hematoxylin and eosin (H\&E) using standard techniques.

\section{Statistical analysis}

Significant differences were calculated by one-way analysis of variance (ANOVA) followed by the Tukey test using the GraphPad Prism software, version 4.0 for Windows (GraphPad Software, San Diego, CA, USA). Values of $\mathrm{P}<0.05$ were considered significant.

\section{Competing interests}

The authors declare that they have no competing interests.

\section{Authors' contributions}

PRM, MAM, HCDM and MG performed the experiments and analyzed the data. FTVP: performed the histopathological analysis. FEM: performed the experimental design, wrote and reviewed the manuscript. All authors read and approved the final manuscript.

\section{Acknowledgement}

The authors are grateful to Christian Hansen Indústria e Comércio Ltda (Valinhos, SP, Brazil) for providing the bixin.

\section{Author details}

${ }^{1}$ Laboratório de Bioquímica Metabólica e Toxicológica (LaBMeT), UNESP Univ Estadual Paulista, Campus de Dracena, Dracena, SP 17900-000, Brazil. ${ }^{2}$ Laboratório de Morfologia da Placenta e Embrião (L@MPE), UNESP - Univ Estadual Paulista, Campus de Dracena, Dracena, SP 17900-000, Brazil.

Received: 6 August 2014 Accepted: 8 August 2014

Published: 29 September 2014

\section{References}

1. Guillouzo A: Liver cell models in vitro toxicology. Environ Health Perspect 1998, 106:511-532

2. Gómez-Lechón MJ, Ponsoda X, Bort R, Castell JV: The use of cultured hepatocytes to investigate the metabolism of drugs and mechanisms of drug hepatotoxicity. Altern Lab Anim 2001, 29:225-231.

3. Boelsterli UA: Xenobiotic-induced oxidative stress: cell injury, signaling and gene regulation. In Mechanistic Toxicology: The molecular basis of how chemicals disrupt biological targets. Boca Raton: CRC Press: Boelsterli UA; 2007:117-175

4. Singh B, Saxena AK, Chandan BK, Anand KK, Suri OP, Suri KA, Satti NK. Hepatoprotective activity of verbenalin on experimental liver damage in rodents. Fitoter 1998, 69:135-140.

5. Shankar NLG, Manavalan R, Venkappayya D, Raj CD: Hepatoprotective and antioxidant effects of Commiphora berryi (Arn) Engl bark extract against $\mathrm{CCl}_{4}$ induced oxidative damage in rats. Food Chem Toxicol 2008, 46:3182-3185.
6. Moresco RN, Sperotto RL, Bernardi AS, Cardoso RF, Gomes P: Effect of the aqueous extract of Syzygium cumini on carbon tetrachloride-induced hepatotoxicity in rats. Phytother Res 2007, 21:793-795.

7. Wu Y, Li L, Wen T, Li YQ: Protective effects of echinacoside on carbon tetrachloride-induced hepatotoxicity in rats. Toxicology 2007, 232:50-56.

8. Ćebović T, Maksimović Z: Hepatoprotective effect of Filipendula hexapetala Gilib. (Rosaceae) in carbon tetrachloride-induced hepatotoxicity in rats. Phytother Res 2012, 26:1088-1091.

9. Essawy AE, Abdel-Moneim AM, Khayyat LI, Elzergy AA: Nigella sativa seeds protect against hepatotoxicity and dyslipidemia induced by carbon tetrachloride in mice. J Appl Pharmac Sci 2012, 2:21-25.

10. Wafay H, El-Saeed G, El-Toukhy S, Youness E, Ellaithy N, Agaibi M, Eldaly S: Potential effect of garlic oil and silymarin on carbon tetrachlorideinduced liver injury. Aust J Basic App/ Sci 2012, 6:409-414.

11. Jondiko IJ, Patterden G: Terpenoids and an apocarotenoid from seeds of Bixa orellana. Phytochemistry 1989, 28:3159-3162.

12. Mercadante $A Z$ : Composition of carotenoids from annatto. In Chemistry and Physiology of Selected Food Colorants. ACS Symposium Series: Washington: AMES JM, Hofman TF; 2001:92-101.

13. Teske M, Trentini AMM: Herbarium: Compêndio de fitoterapia. Curitiba PR: Herbarium Laboratório Botânico; 1994:235-237.

14. Lorenzi H, Matos FJA: Plantas medicinais no Brasil: nativas e exóticas. Nova Odessa SP: Instituto Plantarum; 2002:95-96.

15. Coelho AMSP, Silva GA, Vieira OMC, Chavasco JK: Antimicrobial activity from Bixa orellana L. (Urucum). Rev Lecta 2003, 21:47-54.

16. Ferreira JM, Sousa DF, Dantas MB, Fonseca SGC, Menezes DB, Martins AMC, Queiroz MGR: Effects of Bixa orellana L. seeds on hyperlipidemia. Phytother Res 2013, 27:144-147.

17. Mascio DIP, Devasagayam TP, Kaiser S, Sies H: Carotenoids, tocopherols and thiols as biological singlet molecular oxygen quenchers. Biochem Soc Trans 1990, 18:1054-1056.

18. Zhang LX, Cooney RV, Bertram JS: Carotenoids enhance gap junctional communication and inhibit lipid peroxidation in $\mathrm{C} 3 \mathrm{H} / 10 \mathrm{~T} 1 / 2$ cells: relationship to their cancer chemopreventive action. Carcinogenesis 1991, 12:2109-2114

19. Mercadante AZ, Pfander H: Carotenoids from annatto: a review. Recent Res Dev Agric Food Chem 1998, 2:79-91.

20. Preston HD, Rickard MD: Extraction and chemistry of annatto. Food Chem 1980, 5:47-56

21. Scotter M: The chemistry and analysis of annatto food colouring: a review. Food Addit Contam Part A 2009, 26:1123-1145.

22. Lima LRP, Oliveira TT, Nagem TJ, Pinto AS, Stringheta PC, Tinoco ALA, Silva JF: Bixin, norbixin and quercetin and lipid metabolism effects in rabbits Braz J Vet Res An Sci 2001, 38:196-200.

23. Barcelos GR, Grotto D, Serpeloni JM, Aissa AF, Antunes LM, Knasmüller $S$, Barbosa F Jr: Bixin and norbixin protect against DNA-damage and alterations of redox status induced by methylmercury exposure in vivo. Environ Mol Mutagen 2012, 53:535-541.

24. Santos GC, Mendonça LM, Antonucci GA, Santos AC, Antunes LMG, Bianchi MLP: Protective effect of bixin on cisplatin-induced genotoxicity in PC12 cells. Food Chem Toxicol 2012, 50:335-340.

25. Pavanato A, Tuñón MJ, Sánchez-Campos S, Marroni CA, Llesuy S, GonzálezGallego J, Marroni N: Effects of quercetin on liver damage in rats with carbon tetrachloride-induced cirrhosis. Dig Dis Sci 2003, 48:824-829.

26. Lee $\mathrm{KJ}$, Choi $\mathrm{JH}$, Jeong HG: Hepatoprotective and antioxidant effects of the coffee diterpenes kahweol and cafestol on carbon tetrachlorideinduced liver damage in mice. Food Chem Toxicol 2007, 45:2118-2125

27. Quan J, Piao L, Wang X, Li T, Yin X: Rossicaside B protects against carbon tetrachloride-induced hepatotoxicity in mice. Basic Clin Pharmacol Toxicol 2009, 105:380-386.

28. Srivastava A, Shivanandappa T: Hepatoprotective effect of the root extract of Decalepis hamiltonii against carbon tetrachloride-induced oxidative stress in rats. Food Chem 2010, 118:411-417.

29. Recknagel RO, Glende JREA, Dolak JA, Waller RL: Mechanisms of carbon tetrachloride toxicity. Pharmacol Ther 1989, 43:139-145.

30. Jimenez W, Clària J, Arroyo V, Rodés J: Carbon tetrachloride induced cirrhosis in rats: an useful tool for investigating the patogenesis in chronic liver disease. J Gastroenterol Hepatol 1992, 7:90-97.

31. Kaplowitz N: Drug-induced liver disorders: Implications for drug development and regulation. Drug Saf 2001, 24:483-490. 
32. Esterbauer $\mathrm{H}$, Schaur RJ, Zollner $\mathrm{H}$ : Chemistry and biochemistry of 4-hydroxynonenal, malonaldehyde and related aldehydes. Free Radic Biol Med 1991, 11:81-128.

33. Guéraud F, Atalay M, Bresgen N, Cipak A, Eckl PM, Huc L, Jouanin I, Siems W, Uchida K: Chemistry and biochemistry of lipid peroxidation products. Free Radic Res 2010, 44:1098-1124.

34. Ross D, Moldeus P: Antioxidant defense systems and oxidative stress. In Membrane lipid oxidation. Boca Raton: CRC Press: Vigo-Pelfrey C; 1991:151-170

35. Zhao W, Yao S, Wang Q, Qian S, Wang W, Han Y: Reaction of carotenoids with $\mathrm{CCl}_{3} \mathrm{OO}$ by using pulse radiolysis. Sci China Ser B 2003, 46:57-63.

36. Silva CR, Antunes LMG, Bianchi MLP: Antioxidant action of bixin against cisplatin-induced chromosome aberrations and lipid peroxidation in rats. Pharmacol Res 2001, 43:561-567.

37. Cain K, Skilleter DN: Preparation and use of mitochondria in toxicological research. In Biochemical Toxicology. Oxford: IRL Press: Snell K, Mullock B; 1987:217-254

38. Buege JA, Aust SD: Microsomal lipid peroxidation. Methods Enzymol 1978, 52:302-310.

39. Hissin PJ, Hilf RA: A fluorometric method for determination of oxidized and reduced glutathione in tissues. Anal Biochem 1976, 74:214-226.

doi:10.1186/0717-6287-47-49

Cite this article as: Moreira et al:: Protective effect of bixin on carbon tetrachloride-induced hepatotoxicity in rats. Biological Research 2014 47:49

\section{Submit your next manuscript to BioMed Central and take full advantage of:}

- Convenient online submission

- Thorough peer review

- No space constraints or color figure charges

- Immediate publication on acceptance

- Inclusion in PubMed, CAS, Scopus and Google Scholar

- Research which is freely available for redistribution 